\title{
DIAMOND EXPLORATION: FUNDAMENTALS AND OPPORTUNITIES IN SOUTH AMERICA
}

\author{
LUIZ A. BIZZI ${ }^{1}$
}

\begin{abstract}
The forthcoming development of the Guaniamo and maybe the Canastra kimberlites represents a paradigm shift for diamond exploration in South America and will impact on its diamond production, which has been stagnant at about 1.3 to 1.8 million carats per year and dependent on small dredging operations.

The delineation of prospectable ground in the mid- to late-Archaean São Francisco craton is constrained (i) by the presence of a deep-seated depleted component identifiable in the kimberlites of potential economic significance, (ii) by the lack of evidence for an Achaean protolith underneath its thoroughly explored southwestern margin, and (iii) by widespread lithospheric damage caused by tectonic overthickening in marginally cratonic areas at the end of the Braziliano. The setting of deeply derived alkaline magmatism in the southern São Francisco craton was linked to flexural isostatic uplift and large loading stresses from underlying hot, low density, depleted mantle material. Dissipation of accumulated bending stresses along zones of failure controlled the emplacement of shallower magmas.

The deeper and more depleted component identified in the São Francisco region is also present in kimberlites from Juina in the Brazilian Amazon region. The prospectivity of the Amazon craton is enhanced by the association of kimberlite-related intracontinental magmatism to mantle plumes and the coupling of the time-integrated $\mathrm{Sr}$ and $\mathrm{Nd}$ signatures of some kimberlites, the latter construed to indicate local preservation from lithospheric damage. The source region entrained by the Juina kimberlites is inferred to extend down to the thermo elastic discontinuity that separates upper mantle from lower-mantle at 400-670 Km where majoritic garnets and pyrope with exsolved pyroxene equilibrated as inclusions in diamonds, or even lower, because of the presence of magnesiowüstite and ferripericlase inclusions which is consistent with silicate perovskite paragenesis and derivation from lower mantle below the $670 \mathrm{Km}$ discontinuity. There is no evidence that majoritic garnets encapsulated in the São Luis diamonds were equilibrated at shallower depths before being sampled by kimberlite magmas.

A cool paleogeotherm, minimal asthenospheric imprint and equilibration of diamond inclusions at $41.4-61.5 \mathrm{~Kb}$ and $1200 \mathrm{C}$ in the Guaniamo area imply that economically-significant discrete mantle domains in the Guiana craton may straddle the margins of Achaean ground as mapped at surface. The Dachine diamonds reported from Proterozoic island-arc sequences in French Guiana lack economic interest but point out to the favorable conditions in terms of oxygen fugacity prevalent in the local mantle, which is mostly Achaean in age, at the time of the carbon influx.
\end{abstract}

Keyıvords: diamonds, South America, Sao Francisco craton, Amazon craton, Guiana craton, kimberlites.

INTRODUCTION The objectives of this summary paper are to introduce the fundamentals of diamond exploration in South America and to briefly discuss aspects of the source characteristics of South American kimberlites.

Mantle samples and the source region of kimberlites are used to assess the nature of the South American sub continental mantle lithosphere and the first order prospectivity of the Continent's main diamond producing areas.

DIAMOND INDUSTRY IN SOUTH AMERICA Alluvial diamonds have been known to occur in South America since the early 1700's and bona fide kimberlites since the late 1960's (Barbosa 1991). The South American diamond production, however, has been stagnant at about 1.3 to 1.8 million carats per year and dependent on small dredging operations on major rivers draining Proterozoic sediments of the Roraima plateau (northern Brazil, Venezuela and Guyana) and younger alluvial deposits in the Mato Grosso and Minas Gerais states of Brazil.

The South American present-day and older secondary deposits can be significant in terms of revenue per carat but are of limited significance in terms of world production (Table 1). With a few exceptions of limited economic significance, no success has been achieved on defining the origin of the secondary diamond occurrences and the age and location of their primary sources.

Systematic prospecting programs aimed at primary sources in South America are yet to yield a world class primary deposit, but the forthcoming development of the Guaniamo (Chandler et al., this volume) and maybe the Canastra primary sources represents a paradigm shift for diamond exploration in the Continent. The potential for primary sources has now been proven and there are well-constrained evidences for sampling well within the Diamond Stability Field in all South American diamond producing shield areas. Present-day's investment of about US\$ 40 million per year on grass-roots exploration for diamonds in South America is unprecedented and may provide the means by which to unlock the untapped potential of the Continent for world class diamond deposits.

THE SÃO FRANCISCO CRATON High quality alluvial diamonds have been recovered in the southern São Francisco craton and its margins since 1714 (Barbosa 1991). The existence of Proterozoic or older primary sources is attested by middle-Proterozoic diamond-bearing conglomerates of the Sopa-Brumadinho Formation (e.g. Dossin et al. 1985) which 
have supported extensive diamond mining activities in the Diamantina area. A nearby Cretaceous primary source for the diamonds from upper-Cretaceous diamond-bearing polymictic conglomerates in the Romaria mine has been suggested on the basis of heavy mineral characteristics (e.g. Svisero \& Meyer 1981). Except for the established mines in these two areas, all the other numerous small-scale diamond activities in the southern São Francisco craton area are restricted to recent alluvial deposits.

The Canastra and Tres Ranchos kimberlites are two of the few intrusives in the southern São Francisco craton reported to contain sufficient diamonds to come nearer to economic interest. The debate on the economic nature of kimberlites in the region has been hampered by the inclusion of both kamafugites and kimberlites in the statistics and by not taking into consideration aspects such as erosion and systematic

Table I - South American diamond production

\begin{tabular}{|c|c|c|c|}
\hline Country & $\begin{array}{c}\text { Carats } \\
(, 000)\end{array}$ & $\begin{array}{l}\text { Value } \\
(\$ \mathrm{~m})\end{array}$ & \\
\hline Botswana & 21,384 & 1,612 & \\
\hline Russia & 16,200 & 1,523 & \\
\hline South A frica & 9,733 & 985 & \\
\hline D. R. Congo & 22.000 & 725 & \\
\hline Angola & 3,625 & 544 & \\
\hline Australia & 29,784 & 437 & \\
\hline Canada & 2,510 & 422 & \\
\hline Namibia & 1,611 & 413 & \\
\hline Sierra Leone & 600 & 138 & \\
\hline Guinea & 550 & 120 & \\
\hline Central A frica Republic & 450 & 92 & \\
\hline Venezuela & 450 & 58 & \\
\hline Brazil & 900 & 41 & \\
\hline Tanzania & 232 & 37 & \\
\hline Liberia & 200 & 32 & South America \\
\hline Ivory Coast & 165 & 24 & $1,361 \mathrm{mcts}$ \\
\hline Ghana & 500 & 19 & U\$ $100 \mathrm{~m}$ \\
\hline China & 146 & 15 & \\
\hline Lesotho & 43 & 15 & \\
\hline Guyana & 11 & 1 & \\
\hline Total & 111,058 & 7,253 & \\
\hline
\end{tabular}

variations in rock types and geochemistry on a regional scale. Such variations are now known to represent vertical geochemical heterogeneities, which are translated into lateral heterogenenities by different depths of melting, and to bear upon the perceived potential of local kimberlites with respect to diamonds.

The Proterozoic rocks that overly and flank to the southwest the São Francisco craton margin are intruded by kamafugites, carbonatites and kimberlites that either interacted extensively with, or were derived from, a LREE-enriched homogeneous lithospheric mantle source entrained in plume-derived smallvolume melts. The source characteristics of the rock types are clearly distinct, with kimberlites having lower time-averaged $\mathrm{Rb} / \mathrm{Sr}, \mathrm{Nd} / \mathrm{Sm}, \mathrm{Pb} / \mathrm{U}$ and $\mathrm{Re} / \mathrm{Os}$ ratios than kamafugites.
Systematic variations in isotopic compositions are interpreted as mixing of EMI-like mantle material with variable amounts of a deeper, plume-derived, HIMU-like component (Bizzi et al. 1994, 1995). There is empirical evidence that the EMI-like component equilibrated outside the diamond stability field whilst potential economic significance can be assigned to the more deeply derived component.

To date no evidence has been found for an Achaean protolith underneath the southwestern margin of the mid- to late-Achaean São Francisco craton. To the contrary, combined $\mathrm{Nd}$ and $\mathrm{Os}$ isotopic signatures for Precambrian mafic complexes and the Paranaíba volcanics provide evidence for lithospheric mantle accretion at 1.3-1.4 Ga. Overall, the radiogenic isotopes are consistent with a sequence of events in which the local mantle lithosphere was enriched in incompatible elements during the evolution of the Brasilia Belt (Bizzi et al. 1995) and define the western limits of prospectable ground.

Isotopic similarities between the kimberlites in the southern São Francisco craton and Dupal-type OIB's in the South Atlantic (viz. Walvis Ridge) suggest that their source region was influenced by the Tristan da Cunha Dupal hotspot (Bizzi et al. 1994 and 1995). Such similarity has been ascribed to processes by which continental lithosphere became first delaminated, and then contaminated a zone of South Atlantic asthenosphere from which hot-spot islands have been erupting (Bizzi et al. 1995, Bizzi et al. 2002).

The similarity of isotopic signatures reported for the kimberlites intruded in the southwestern margin relative to those signatures obtained for kimberlites intruded in the northern São Francisco craton and elsewhere in northeastern Brazil led to the proposal that widespread lithospheric damage and delamination probably took place following tectonic over thickening at the end of the Braziliano (Bizzi et al. 1995, Bizzi \& Pimentel 1998). Inasmuch as the density inversion would result of in situ gabbro-eclogite-granulite phase transformations accompanied by $\mathrm{CO}_{2}$ metasomatism, the chances of diamond preservation in such a scenario would be down rated even if the delamination of the local enriched lithosphere was incomplete.

Source characteristics, emplacement ages of kimberlites and related rocks and apatite fission track data for the Northern São Francisco (Harman et al. 1997) are consistent with and can be construed as evidence for a sequence of events in which the setting of deeply derived alkaline magmatism in the southern São Francisco craton was linked to flexural isostatic uplift and large loading stresses from an underlying hot, low density mantle region. The Dupal-type signature of the kimberlites and related rocks and their isotopic similarities to Dupal-type OIB's in Walvis Ridge suggest that their source region was influenced by the Tristan da Cunha Dupal hotspot and not the Trindade hot-spot, which is non-Dupal (Bizzi et al. 1995). Dissipation of accumulated bending stresses and alkaline activity along zones of failure controlled the emplacement of shallower magmas at least up to the end of the Aptian. Following the $110 \mathrm{Ma}$ event, peaks of shallow alkaline magmatism occurred at 83 and $67 \mathrm{Ma}$ and was concomitant to changes in plate motion and assistant dissipation of withinplate stress.

THE AMAZON CRATON Bardet (1977) first suggested 


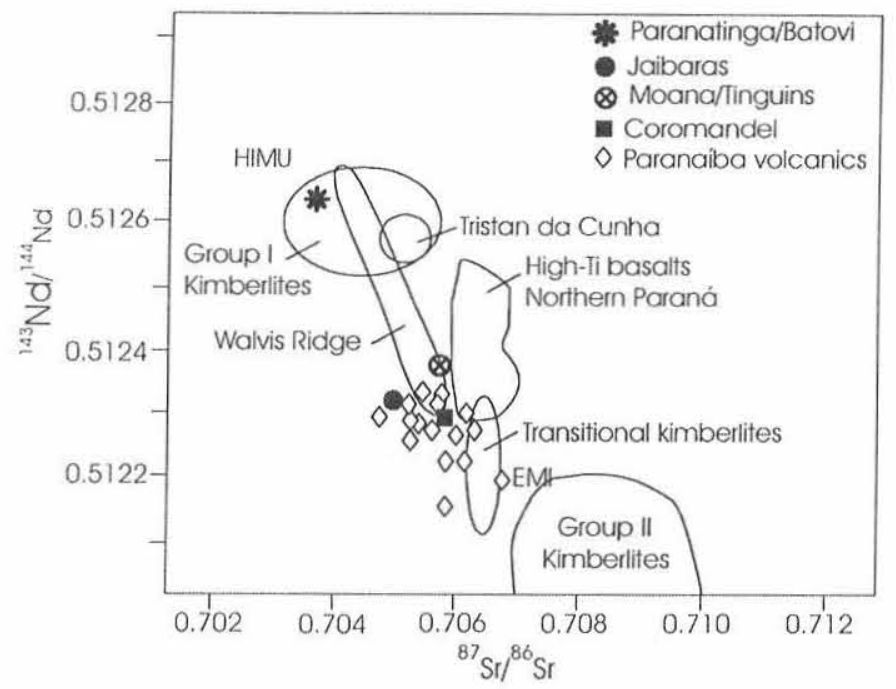

Figure I - Average Sr and Nd signatures for Brazilian kimberlites and related rocks after Bizzi \& Pimentel (1998).

that the kimberlites and kimberlite-related intrusives in Minas Gerais extend northwestward into the Amazon craton along the NW-SE trending lineament $120 \mathrm{AZ}$. The implied association of kimberlite-related intracontinental magmatism to South Atlantic hot-spots (e.g. Crough 1980) and the recognition that kimberlites intruded in the Amazon craton do not share the enriched OIB (Ocean Island Basalts) characteristics of kimberlites intruded elsewhere in South America (Bizzi \& Pimentel 1998; Fig. 1) add a new dimension to the discussion of mantle plumes and deep mantle samples along such lineament.

Despite their similarities in bulk composition, mineralogy and petrographic character, the isotopic composition of the kimberlites intruded in the Amazon craton are clearly distinctive when compared to the above mentioned kimberlite provinces in eastern Brazil. Their lower time-averaged $\mathrm{Rb}-\mathrm{Sr}$ and Nd-Sm ratios imply that the ancient enrichment of their source was either not as intense or not as old (or possibly both) as that of the source of their South American counterparts. The coupling of their time-integrated $\mathrm{Sr}$ and $\mathrm{Nd}$ signatures indicate the Amazon craton was preserved from lithospheric damage and delamination at the end of the Braziliano (Bizzi \& Pimentel 1998), the chances of diamond preservation in such a scenario being upgraded.

The emplacement ages of the older Aripuanã kimberlites (ca 200 my; in Bizzi 1993) compared to the Minas Gerais kimberlites, and to the Japecanga kimberlite in particular (ca $110 \mathrm{My}$; Bizzi 1993), are compatible with a NW-SE age progression of emplacement ages along the $120 \mathrm{AZ}$ lineament. If the occurrences in these two provinces (i.e. the Coromandel and Aripuanã kimberlites, which are over $1500 \mathrm{~km}$ apart) were related to a single vertically rising stationary mantle plume yielding OIB-type melts, it can be calculated that the South American plate would have had an average movement of 1.78 $\mathrm{cm} / \mathrm{yr}$ in such period. The hypothetical vector of movement of the South American plate relative to this plume track is sub- parallel to N60W-N65W elongated features on filtered geoid and topography maps of the South Atlantic (Bizzi et al. 2002). Dissipation of accumulated bending stresses was also instrumental in controlling the emplacement of alkaline magmas along zones of failure that have undergone metasomatism (e.g. recurrence of kimberlite magmatism in the Juína Province in 92-95 Ma as reported by Teixeira and co-authors; this volume).

Eclogitic inclusions extracted from diamonds recovered from the São Luis alluvial deposits point to mantle depths of at least $400 \mathrm{~km}$ and may be even $650 \mathrm{~km}$, and their overall chemical characteristics reflect a deep asthenospheric source for the diamonds (Bizzi 1999 and references therein). Although clino-pyroxene has the form of possible exsolution lamellae with garnet, eventually with majorite type substitution, the chemical compositions indicate that this clinopyroxene could not have been produced together with normalsilicon garnets during decomposition of high-silicon garnets. Thus, unlike the majoritic diamond inclusions in the Monastery (Moore and Gurney 1985) and Jaggersfontain (Sautter \& Haggerty 1991) kimberlites in South Africa, there is no evidence so far that majoritic garnets encapsulated in the São Luis diamonds were transported to/equilibrated at shallower depths before being sampled by kimberlite magmas.

Araujo et al. (this volume) studied in excess of 200 diamonds from sub-economic diamond-bearing kimberlites and terraces nearby in the Aripuanã area for their cathode luminescence (CL) features, spectral classification (FTIR), C and $\mathrm{N}$ isotope and $\mathrm{N}$ content. Nitrogen-free (type II) diamonds were found to predominate among alluvial and primary diamond populations and have also been related to the deep mantle. Type I diamonds present low- $\mathrm{N}$ content and are highly aggregated. The data obtained supports suggestions elsewhere that the lower mantle would be homogeneous in respect to Carbon isotopes while the transition zone bellow the SW border of the Amazon Craton would be characterized by lighter Carbon isotope values.

THE GUIANA CRATON Diamonds were first discovered in the Caroni river in 1925 and Venezuelan diamond production out of small dredging operations on major rivers draining Proterozoic sediments of the Roraima plateau has averaged some 500 thousand carats a year. The Guianese production has averaged a further 15 thousand carats a year. The forthcoming development of the Guaniamo kimberlites (Chandler et al., this volume) and the recognition of microdiamond bearing primary sources in the Inini area of French Guiana have shed new interest in the region.

Notwithstanding the fact that the Guaniamo kimberlites were intruded outside the limits of proven Achaean terranes of the Imataca complex, Ni-thermometry reported for the Guaniamo area indicates a cool paleogeotherm. The lack of discrete nodules (megacrysts) and sheared garnet lherzolite suites in the Guaniamo kimberlites indicate minimal asthenospheric imprint. Diamond inclusions dominated by silica-rich assemblages (coesites, omphacites, garnets, corundum) and a few coexisting garnets and clino-pyroxenes equilibrated at $41.4-61.5 \mathrm{~Kb}, 1200 \mathrm{C}$. The reconciliation of such observations and the depleted nature of the garnets (Fig. 2) with a Proterozoic accretion age for the local crust can best be attained by assuming that upper crust and lithospheric mantle might have somehow been decoupled, the implication 
being that prospecting for economically-significant discrete mantle domains must straddle the margins of Achaean ground as mapped at surface.

Capdevilla et al. (1999) have ascribed the Dachine diamonds in French Guiana to volcaniclastic komatiites that are part of a $2.11 \mathrm{Ga}$ island-arc sequence. Although the diamond population is dominated by micro diamonds, $+1 \mathrm{~mm}$ diamonds can be locally abundant, with bulk samples containing up 77 micro diamonds per kilo and grades reaching $4 \mathrm{cts} / \mathrm{m} 3$ in poorly sorted alluvium overlying mineralized bedrock. The largest reported diamond is $4.6 \mathrm{~mm}$ in diameter. The garnet population is dominated by lherzolitic types with subordinate harzburgitic and eclogitic types. Other minerals commonly associated with kimberlite are absent. Chromites are poorer in $\mathrm{Ti}$ and richer in $\mathrm{Mn}$ than those commonly found in kimberlites.

Interestingly enough, mostly (>99\%) E-type diamonds with anomalous negative values of carbon isotope composition have been reported for both the Guaniamo and the Inini diamond occurrences.

Acknowledgments To Carlos Schobbenhaus, Luciano Borges and reviewers of RBG for suggestions to the manuscript.
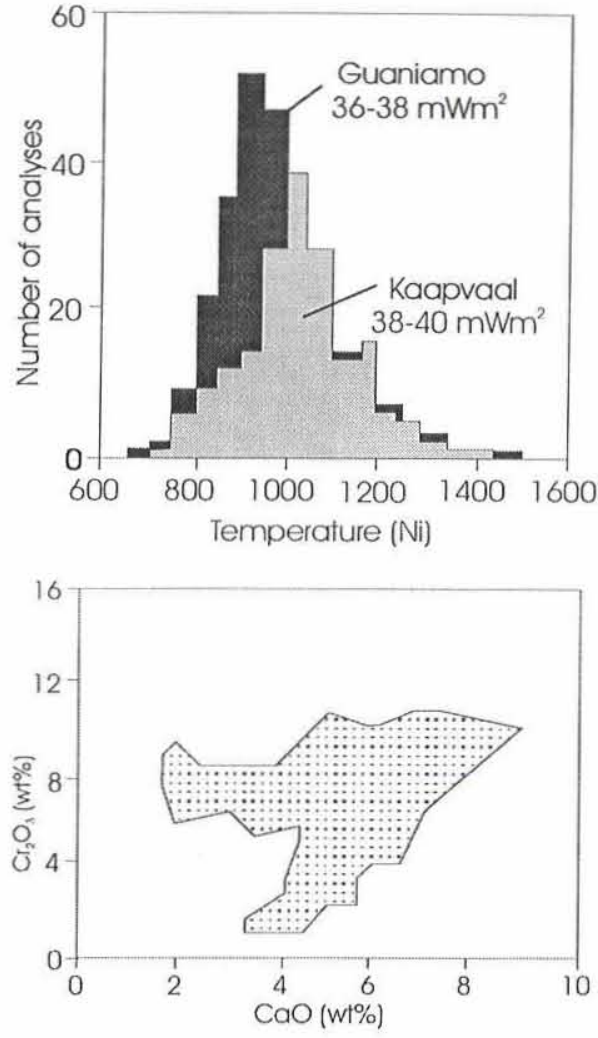

Figure 2 - Temperature profiles (on the basis of $\mathrm{Ni}$ thermometry) and garnet major element signatures for the Guaniamo kimberlites.

\section{References}

Barbosa O. 1991. Diamante no Brasil: histórico, ocorrência, prospeç̧ão e lavra. CPRM, 1991.

Bardet M.G. 1977. Geologie du Diamant. Troisieme Parte: Gisements de diamants d'Asia, d'Amerique, d'Europe et d'Australasia. Bureau de Recherches Geologiques et Minieres. Memoir 83, $169 \mathrm{p}$.

Bizzi L.A. 1993. Mesozoic alkaline volcanism and mantle evolution of the southwestern São Francisco Craton. PhD Thesis, Department of Geological Sciences, University of Cape Town, RSA.

Bizzi L.A, Smith C.B., de Wit M.J., Armstrong R.A., Meyer H.O.A. 1994. Mesozoic kimberlites and related alkalic rocks in SW São Francisco craton, Brazil: a case for local mantle reservoirs and their interaction. International Kimberlite Conference, 5, Extended Contributions, Vol. 1, pp.:156-171.

Bizzi L.A, de Wit M.J., Smith C.B., Mc Donald I., Armstrong R.A. 1995. Heterogeneous enriched mantle materials and Dupal-type magmatism along the SW São Francisco Craton Margin, Brazil. Journal of Geodynamics, 20:469-491

Bizzi L.A, Smith C.B., de Wit M.J., Me Donald I., Armstrong R.A. 1995 Compositional heterogeneity of the lithospheric mantle underlying the SW São Francisco craton margin, Brazil. Proceedings of the Brazilian Academy of Sciences. Invited Contribution, pp.:

Bizzi L.A.\& Pimentel M. 1998. Source Characteristics of Brazilian Kimberlites. International Kimberlite Conference, 7, Cape Town, South Africa, Proceedings, $\mathrm{pp}$.

Bizzi L.A. 1999. Diamonds and kimberlite mantle sources in the Amazon. In: SBG, International Symposium on the Geology of the Amazon, 6, Manaus, Invited Seminars, pp.:
Bizzi L.A., Vidotti R.M, Milani E. 2002. Post-Gonwana Geodynamics and fissionrelated magmatism. Chapter in book volume by Bizzi et al. (Eds) Geology, Tectonics and Mineral Resources of Brazil, CPRM, 2002 (in press).

Capdevilla R., Arndt N. Letendre J., Sauvage J.F. 1999. Diamonds in volcaniclastic komatiite from French Guiana. Nature 3991:456-457.

Crough S.T., Morgan W.J. and Hargreaves R.B. 1980. Kimberlites: their relation to mantle hotspots. Ear. Planet. Sci. Let., 50:260-274.

Dossin L.A., Chaves M.L.S.C., Uhlein A., Alvarenga C.J.S. 1985. Geologia e depósitos diamantíferos da região de Sopa-Diamantina, MG. In: SBG, Simp. Geol., Minas Gerais, 3, Anais, pp.: 276-289.

Harman, R., Gallagher, K., Brow, R., Raza A. and Bizzi L.A. (1998) Accelerated denudation and tectonic/geomorphic reactivation of the cratons of northeastern Brazil during the late Cretaceous. Journal of Geophysical Research v.103, n811, pp 27091-105.

Moore R.O. \& Gurney J.J. 1985. Pyroxene solid solution in garnets included in diamond. Nature 318:553-555.

Sautter V., Haggerty S.E. and Field S. (1991) Ultradeep (greater-than-300 kilometers) ultramafic xenoliths - petrological evidence from the transition zone. Science 252: (5007) 827-830.

Svisero D.P. \& Meyer H.O.A. 1981. Ilmenitas kimberlíticas da mina de diamantes de Romaria: composição química e origem. Bol. Mineralógico, 6:7-14.

Manuscrito A-1316 Recebido em 07 de dezembro de 2001 Revisão do autor em 28 de dezembro de 2001 Revisão aceita em 29 de dezembro de 2001 